\title{
Associated Detection of Superoxide Anion and Mercury(II) under Chronic Mercury Exposure in Cells and Mice Models via a Three- Channel Fluorescent Probe
}

\author{
Yue Wang, ${ }^{\dagger}, \|$ Min Gao, ${ }^{\dagger, \|}$ Qingguo Chen, ${ }^{\S}$ Fabiao Yu, ${ }^{*}, \dagger, \S_{\odot}$ Guibin Jiang, ${ }^{\ddagger}$ and Lingxin Chen ${ }^{*}, \dagger, \S_{(0)}$ \\ ${ }^{\dagger}$ CAS Key Laboratory of Coastal Environmental Processes and Ecological Remediation, Research Center for Coastal Environmental \\ Engineering and Technology, Yantai Institute of Coastal Zone Research, Chinese Academy of Sciences, Yantai 264003, China \\ ${ }^{\ddagger}$ State Key Laboratory of Environmental Chemistry and Ecotoxicology, Research Center for Eco-Environmental Sciences, Chinese \\ Academy of Sciences, Beijing 100085, China \\ ${ }^{\S}$ School of Marine Science and Technology, Zhejiang Ocean University, Zhoushan 316022, China \\ "University of Chinese Academy of Sciences, Beijing 100049, China
}

Supporting Information

\begin{abstract}
As a cytotoxic heavy metal ion, mercury(II) ion $\left(\mathrm{Hg}^{2+}\right)$ induces severe oxidative stress and further results in physiological dysfunction. Although mercury poisoning can be treated with many drugs, such as sodium selenite, the therapeutic effect is relatively poor, and it seems that the damage to human health continues. However, the interpretation for the pathogenesis has not been clarified yet. We supposed that the reason is attributed to $\mathrm{Hg}^{2+}$-caused intracellular oxidative stress. To confirm our hypothesis, we strived to design a threechannel ratio fluorescent probe, $\mathrm{HCy}-\mathrm{SeH}$, for superoxide anion $\left(\mathrm{O}_{2}{ }^{--}\right)$ and $\mathrm{Hg}^{2+}$ combined detection. $\mathrm{O}_{2}{ }^{\bullet-}$ is a vital precursor for other reactive oxygen species (ROS), which is involved in many physiological and pathological processes. However, until now there is no efficient chemical tool for $\mathrm{O}_{2}{ }^{--}$and $\mathrm{Hg}^{2+}$ combined detection in cells and in vivo. The

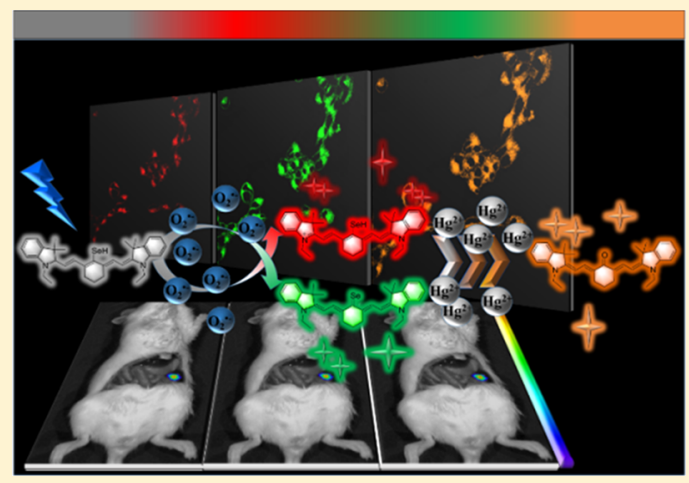
fluorescence response of our probe is initiated by a hydrogen abstraction reaction from the hydrocyanine fluorophore moiety. Once oxidized by $\mathrm{O}_{2}{ }^{\bullet-}, \mathrm{HCy}-\mathrm{SeH}$ recovers its $\pi$-conjugated system back to a heptamethine cyanine derivative, $\mathrm{Cy}-\mathrm{SeH}$. Cy$\mathrm{SeH}$ coexists with its conjugate base, $\mathrm{Cy}=\mathrm{Se}$. One emits red fluorescence, and the other one emits green fluorescence. The response unit, $-\mathrm{SeH}$, can trap $\mathrm{Hg}^{2+}$ via a $\mathrm{Se}-\mathrm{Hg}$ antagonism reaction to afford an orange-emitting final product, Keto-Cy. The probe offers high selectivity and sensitivity toward $\mathrm{O}_{2}{ }^{\circ-}$ and $\mathrm{Hg}^{2+}$. When applied for $\mathrm{O}_{2}{ }^{\bullet-}$ and $\mathrm{Hg}^{2+}$ detection in $\mathrm{HEK} 293$ cells, the imaging results indicate that our probe can provide a combined response for $\mathrm{O}_{2}{ }^{--}$and $\mathrm{Hg}^{2+}$ in real time and in situ. Flow cytometry analysis is well-consistent with the results from fluorescence imaging. When applied to image $\mathrm{O}_{2}{ }^{\bullet-}$ and $\mathrm{Hg}^{2+}$ in mice models, we find that $\mathrm{Hg}^{2+}$ dominantly accumulates in the kidney and induces a burst of $\mathrm{O}_{2}{ }^{\bullet-}$. We confirm that chronic mercurialism can cause severe oxidative damage and renal fibrosis. $\mathrm{HCy}-\mathrm{SeH}$ further provides a new information that, even when intracellular $\mathrm{Hg}^{2+}$ has been antagonized, the outbreak of $\mathrm{O}_{2}^{\bullet-}$ caused by mercury poisoning still lasts.
\end{abstract}

$\mathrm{E}$ nvironmental pollution caused by mercury(II) ion $\left(\mathrm{Hg}^{2+}\right)$ seriously threatens human health. ${ }^{1,2}$ The pollution of $\mathrm{Hg}^{2+}$ comes from a variety of ways, such as primary metals production, fossil fuel burning, chemical manufacturing, coal mining, and so on. $\mathrm{Hg}^{2+}$ can exist in the environment for a long time. The reason why $\mathrm{Hg}^{2+}$ behaves as a fatal heavy metal ion is that it always forms chelates with intracellular electron donors, such as mercapto, carboxyl, carbonyl, and amino. All these groups are expected to play important roles in antioxidant proteins or enzymes. Therefore, mercury poisoning gives rise to many diseases such as central nervous system damage, various cognitive and motor disorders, kidney failure, and even death. ${ }^{3-5}$ Studies show that $\mathrm{Hg}^{2+}$ can damage many organs, but the kidney suffers the most serious injury. ${ }^{6}$ That is, men who are engaged in the mercury-related industry will be inevitably exposed to the mercury-contaminated environment and may suffer from chronic mercury poisoning and other mercury-related diseases. Now many drugs, such as sodium selenite, facilitate the treatment of mercury poisoning. However, the prognosis of therapeutic efficacy is often unsatisfactory. There is much evidence that reveals that $\mathrm{Hg}^{2+}$ can be effectively alleviated by many drugs, but its disease symptoms cannot be thoroughly eliminated for a long time. However, the related pathological mechanisms have not yet been clearly elaborated. We suppose that the reason must have

Received: March 30, 2018

Accepted: July 20, 2018

Published: July 20, 2018 
a close relationship to $\mathrm{Hg}^{2+}$-induced oxidative stress via the damage to the intracellular oxidoreductase.

Superoxide anion $\left(\mathrm{O}_{2}{ }^{--}\right)$is the precursor of other reactive oxygen species (ROS). ${ }^{7-9}$ It is an important intermediate in many important physiological and pathological processes. Its intracellular level may reflect the overall concentrations of other ROS. Bodies benefit from a normal level of $\mathrm{O}_{2}{ }^{\bullet-}$. However, the excessive production of $\mathrm{O}_{2}{ }^{--}$will result in organism damage, and this allows us to uphold our hypothesis. The mercury-induced burst of $\mathrm{O}_{2}{ }^{--}$is available in two ways. One path is that $\mathrm{Hg}^{2+}$ induces the lipid peroxide, causing the $\mathrm{O}_{2}{ }^{\bullet-}$ burst. ${ }^{10}$ The other path is that $\mathrm{Hg}^{2+}$ connects with the mercapto group on the antioxidants such as glutathione and metallothionein, deactivating the antioxidants to induce the overproduction of $\mathrm{O}_{2}^{\bullet-11,12} \mathrm{O}_{2}^{\bullet-}$ is involved in many pathological processes, ${ }^{13,14}$ such as Parkinson's disease, atherosclerosis, autism, and Alzheimer's disease. ${ }^{15,16}$ Thus, the combined detection of intracellular $\mathrm{O}_{2}^{\bullet-}$ and $\mathrm{Hg}^{2+}$ changes contributes to understanding their physiological functions and to elucidating the reason for the poor prognosis.

Due to the complex mechanism between $\mathrm{O}_{2}{ }^{--}$and $\mathrm{Hg}^{2+}$ involved in many physiological and pathological processes, the interaction of $\mathrm{O}_{2}{ }^{--}$and $\mathrm{Hg}^{2+}$ has become a valuable research area which needs to be further interpreted. There are two major challenges for the associated detection of $\mathrm{O}_{2}{ }^{--}$and $\mathrm{Hg}^{2+}$. On the one hand, $\mathrm{O}_{2}^{\bullet-}$ has rapid catabolism properties due to its high reactivity. On the other hand, the sample treatment is too complicated to detect $\mathrm{Hg}^{2+}$ in vivo. Many technologies have been applied to detect $\mathrm{O}_{2}{ }^{--}$or $\mathrm{Hg}^{2+}$ separately. For example, the traditional analytical methods for $\mathrm{O}_{2}{ }^{--}$detection are usually based on mass spectrometry (MS), electron spin resonance spectroscopy, and highperformance liquid chromatography (HPLC). ${ }^{17-19}$ The commonly adopted analytical methods that are used for $\mathrm{Hg}^{2+}$ detection are based on atomic absorption spectrometry, atomic emission spectrometry, electron paramagnetic resonance (EPR), and nuclear magnetic resonance (NMR). ${ }^{20,21}$ However, these detection methods require complicated sample pretreatment and destruction of tissue or cells. It is difficult to achieve in situ and real-time detection in cells and in vivo. Additionally, they also cannot realize a combined response of $\mathrm{O}_{2}{ }^{\bullet-}$ and $\mathrm{Hg}^{2+}$ during the complicated process. Compared to other biological detection technologies, fluorescence bioimaging technology has powerful potential in the field of bioanalysis because of its high spatial and temporal resolution, good selectivity, excellent sensitivity, less invasiveness, and rapid response. $^{22-26}$ So far, fluorescent probes for the detection of $\mathrm{O}_{2}{ }^{\bullet-}$ and $\mathrm{Hg}^{2+}$ have been elegantly developed, respectively. ${ }^{27-39}$ However, the combined-response fluorescent probe for $\mathrm{O}_{2}{ }^{\bullet-}$ and $\mathrm{Hg}^{2+}$ associated detection is urgently required, because the relationship between $\mathrm{O}_{2}{ }^{--}$and $\mathrm{Hg}^{2+}$ is of great complexity which relates to many diseases. To the best of our knowledge, no fluorescent probe has been developed to date for $\mathrm{O}_{2}{ }^{--}$and $\mathrm{Hg}^{2+}$ associated detection. For $\mathrm{O}_{2}{ }^{\bullet-}$ and $\mathrm{Hg}^{2+}$ combined-response detection, first, we should screen a selective reaction which can avoid interferences coming from other ROS, such as hydroxyl radicals $\left({ }^{\bullet} \mathrm{OH}\right)$ and hydrogen peroxide $\left(\mathrm{H}_{2} \mathrm{O}_{2}\right)$, to detect $\mathrm{O}_{2}{ }^{--}$in a complex living system. Second, the group used to detect $\mathrm{Hg}^{2+}$ should both specifically respond to $\mathrm{Hg}^{2+}$ and avoid interference from other metal ions, such as the physiologically relevant ions $\mathrm{Zn}^{2+}, \mathrm{Mg}^{2+}$, and $\mathrm{Ca}^{2+}$. For in vivo imaging, the probes whose absorption and emission profiles range in the near-infrared (NIR) region that are able to maximize tissue penetration and to avoid biological background fluorescence will be good candidates for our detection, ${ }^{40-42}$ and the ratio signal which employs the ratio of the fluorescence spectra can minimize the interference induced by the uneven loading or the inhomogeneous distribution. $^{43-47}$

Herein, we described a NIR ratiometric three-channel fluorescent probe, $\mathrm{HCy}-\mathrm{SeH}$, for the associated detection of $\mathrm{O}_{2}{ }^{\bullet-}$ and $\mathrm{Hg}^{2+}$. $\mathrm{HCy}-\mathrm{SeH}$ exhibited desirable abilities, such as rapid response time, three-channel fluorescence emission, and high sensitivity, and it could provide a combined response to $\mathrm{O}_{2}{ }^{--}$and $\mathrm{Hg}^{2+}$ in living cells and in vivo. The fluorescence imaging results indicated that $\mathrm{Hg}^{2+}$ could induce $\mathrm{O}_{2}{ }^{--}$burst in cells. The chronic accumulation of $\mathrm{Hg}^{2+}$ would cause severe oxidative stress and lead to cell apoptosis. The results were confirmed by flow cytometry analysis, and cell morphology was investigated by transmission electron microscopy (TEM). Furthermore, $\mathrm{HCy}-\mathrm{SeH}$ was successfully applied to $\mathrm{O}_{2}{ }^{\bullet-}$ and $\mathrm{Hg}^{2+}$ detection in mice models of chronic mercurialism. Importantly, with the help of $\mathrm{HCy}-\mathrm{SeH}$, we found that, although the $\mathrm{Hg}^{2+}$ could be antagonized by sodium selenite, the overexpressed $\mathrm{O}_{2}{ }^{\bullet-}$ still lasted and caused severe oxidative damage to organisms.

\section{EXPERIMENTAL SECTION}

Establishment of the Cell Model of Chronic Mercurialism. Cells were incubated in 25 Petri dishes. When the cells covered $60 \%$ of the bottom of the whole dish, different concentrations of $\mathrm{Hg}^{2+}$ (groups a, b, c, d, e, and f: 0, 2, 4, 6, 8, and $10 \mu \mathrm{M}$, respectively) were added into the dishes for $12 \mathrm{~h}$ to establish the chronic mercurialism cell models.

Establishment of the $\mathrm{Hg}^{2+}$-Induced Chronic Mercurialism Mice Models. BALB/c mice weighing about 25-30 g were obtained from Binzhou Medical University. Mice were raised in cages; an SPF laboratory diet and water were acquired freely. Mice were group-housed on a 12:12 light-dark cycle with free access to food and water. To model mice, $18 \mathrm{mg} / \mathrm{kg}$ mercury chloride solution was given orally by gavage $(0.2 \mathrm{~mL})$ for different days $(1,3,5,7,9,11$ days); the control mice were given equivalent saline. The mice in the treatment group were given sodium selenite $0.5 \mathrm{mg} / \mathrm{kg}$ and mercury chloride $18 \mathrm{mg} /$ $\mathrm{kg}$.

Synthesis. Compounds were synthesized according to the general procedure, and characterization details are described in the Supporting Information.

Synthesis of the Probe. Compound 2 ( $0.12 \mathrm{~g}, 0.176 \mathrm{mM})$ was dissolved in $10 \mathrm{~mL}$ of EtOH, and then 1.5 equiv of $\mathrm{NaBH}_{4}$ (dissolved in $1 \mathrm{~mL}$ of $\mathrm{EtOH}$ ) was added into the reactive system at $0{ }^{\circ} \mathrm{C}$. After $10 \mathrm{~min}$, the color of the mixture turned to yellow. The mixture was washed with saturated KI solution (bubbled with argon to remove oxygen) for three times and extracted with $\mathrm{CH}_{2} \mathrm{Cl}_{2}$. The crude product purified with $\mathrm{CH}_{2} \mathrm{Cl}_{2} /$ petroleum ether $(1: 1 \mathrm{v} / \mathrm{v})$ obtained $0.049 \mathrm{~g}$ of yellow solid. Yield: $50 \%$. ${ }^{1} \mathrm{H}$ NMR (500 $\left.\mathrm{MHz}, \mathrm{CDCl}_{3}-d_{1}\right) \delta(\mathrm{ppm})$ : $7.18-7.15(\mathrm{t}, 3 \mathrm{H}), 7.08-7.07(\mathrm{~d}, 1 \mathrm{H}), 6.82-6.79(\mathrm{t}, 2 \mathrm{H})$, 6.65-6.64 (d, 2H), $5.33(\mathrm{~s}, 2 \mathrm{H}), 3.48-3.41(\mathrm{~m}, 1 \mathrm{H}), 3.32-$ $3.25(\mathrm{~m}, 1 \mathrm{H}), 2.74-2.64(\mathrm{~m}, 2 \mathrm{H}), 2.59-2.47(\mathrm{~m}, 2 \mathrm{H}), 2.35-$ $2.22(\mathrm{~m}, 2 \mathrm{H}), 1.98(\mathrm{~s}, 1 \mathrm{H}), 1.64-1.62(\mathrm{~d}, 6 \mathrm{H}), 1.47-1.40(\mathrm{~m}$, $5 \mathrm{H}), 1.30-1.26(\mathrm{~m}, 6 \mathrm{H}), 1.14-1.11(\mathrm{t}, 3 \mathrm{H}), 1.07(\mathrm{~m}, 3 \mathrm{H})$. ${ }^{13} \mathrm{C}$ NMR (125 MHz, $\left.\mathrm{CDCl}_{3}-d_{1}\right) \delta(\mathrm{ppm}): 149.37,139.00$, $138.06,130.18,128.64,127.60,127.45,127.23,126.77,125.83$, $125.72,125.06,124.96,124.09,123.98,122.16,118.67,108.38$, 87.92 , 85.35, 53.430, 40.66, 33.512, 31.95, 29.72, 26.49, 25.47, 
Scheme 1. Molecular Structure and the Proposed Mechanism for $\mathrm{O}_{2}{ }^{--}$and $\mathrm{Hg}^{2+}$ Associated Detection

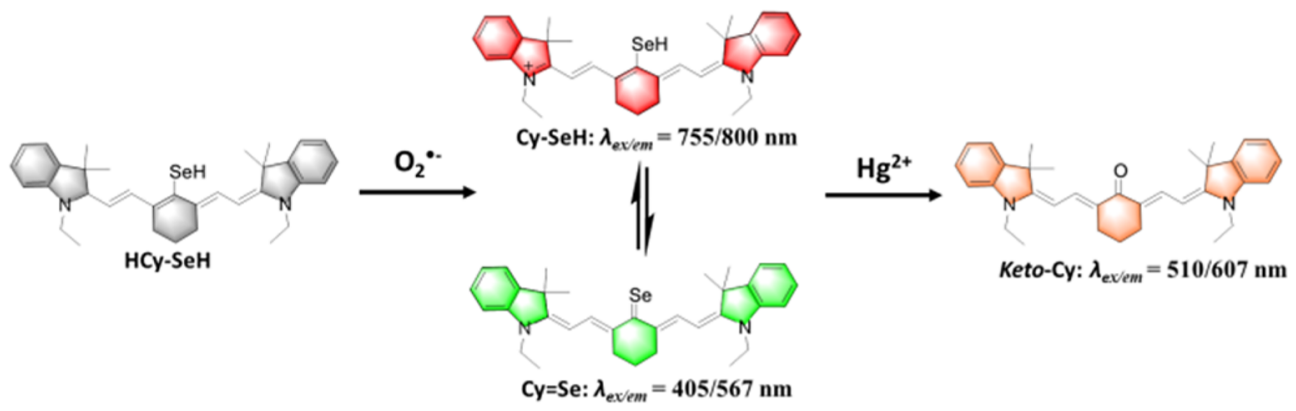

24.36, 22.72, 21.50, 19.33, 15.91, 14.12, 9.97. LC-MS (APIES): $m / z \mathrm{C}_{34} \mathrm{H}_{42} \mathrm{~N}_{2} \mathrm{Se}$; calcd, 558.2513; found $[\mathrm{M}-2 \mathrm{H}]^{+}$, 556.2153

\section{RESULTS AND DISCUSSION}

Design Strategy of the Probes. Due to the complexity of $\mathrm{O}_{2}^{\bullet-}$ and $\mathrm{Hg}^{2+}$ in the chronic mercury poisoning detection, an efficient tool for $\mathrm{O}_{2}{ }^{\bullet-}$ and $\mathrm{Hg}^{2+}$ combined detection is needed urgently. So far as we know, no NIR ratiometric fluorescent probe is used for $\mathrm{O}_{2}{ }^{--}$and $\mathrm{Hg}^{2+}$ associated detection. Our overall strategy for $\mathrm{O}_{2}^{\bullet-}$ and $\mathrm{Hg}^{2+}$ associated response in the biological samples is inspired by two chemical reactions. One is to detect $\mathrm{O}_{2}{ }^{\bullet-}$ through a hydrogen abstraction reaction, ${ }^{48-50}$ and the other is to employ a selenium antagonism reaction ${ }^{51}$ for $\mathrm{Hg}^{2+}$ detection. We choose heptamethine cyanine as the fluorophore because the heptamethine cyanine fluorophore can be reduced for the further detection of $\mathrm{O}_{2}{ }^{\bullet-}$ via hydrogen abstraction reaction (Scheme 1). Moreover, the NIR heptamethine cyanine fluorophore can offer attractive advantages in enlarging tissue penetration and minimizing the absorption of water, myoglobin, hemoglobin, and heme in lipids. ${ }^{52}$ We select a selenol $(-\mathrm{SeH})$ group as the response unit because of the strong antagonism effect between inorganic mercury and selenium. As the solubility product constant is lower $\left(K_{\mathrm{sp} \mathrm{HgSe}}=10^{-59}\right),{ }^{53}$ at least 10 orders of magnitude smaller than that of $\mathrm{HgS}\left(K_{\mathrm{sp} \mathrm{HgS}}=10^{-47}\right)$, the above reaction is feasible for $\mathrm{Hg}^{2+}$ detection in cells, because biothiols, especially glutathione (GSH), concentration is maintained at the millimolar level. We hypothesize that even the $\mathrm{Hg}^{2+}$ in the mercury(II)-glutathione complexes can be easily snatched by selenium. That is, the introduction of a $-\mathrm{SeH}$ group into the molecular structure of the fluorescent probe will be more selective and sensitive for the detection of $\mathrm{Hg}^{2+}$ in cells. ${ }^{54-59}$ We masterly integrated $-\mathrm{SeH}$ into the middle position of the cyanine platform, and then reduced it with sodium borohydride to afford a probe $\mathrm{HCy}-\mathrm{SeH}$ (Scheme 1). The synthetic routes of the probe are described in Scheme S1. As illustrated in Scheme 1, our probe exhibited a capability of three-channel response, which could employ the ratio signal and multicolor imaging to realize a multiresponse with a single fluorescent probe. ${ }^{80}$ Once the $\pi$-electron system of polymethine in cyanine was disturbed by the formation of hydrocyanine, there was no fluorescence emission from $\mathrm{HCy}-\mathrm{SeH}$. After the probe $\mathrm{HCy}-\mathrm{SeH}$ was oxidized by $\mathrm{O}_{2}{ }^{\bullet-}, \mathrm{Cy}-\mathrm{SeH}$ recovered its conjugated system to emit fluorescence. Interestingly, $\mathrm{Cy}-\mathrm{SeH}$ coexists with its Lewis conjugate base, $\mathrm{Cy}=\mathrm{Se}$, in solution. $\mathrm{Cy}-\mathrm{SeH}$ had red emission with an absorption peak centered at $755 \mathrm{~nm}$ and emission peak centered at $800 \mathrm{~nm}$. $\mathrm{Cy}=$ Se exhibited green emission with an absorption peak centered at $405 \mathrm{~nm}$ and emission peak centered at $567 \mathrm{~nm}$. After being reacted with $\mathrm{Hg}^{2+}$, the final product Keto-Cy formed with a maximum absorption at $510 \mathrm{~nm}$ and an emission peak located at $607 \mathrm{~nm}$. $\mathrm{HCy}-\mathrm{SeH}$ relies on analyte-induced changes in the signal of three emission bands to circumvent inexact complications and greatly improves quantification through an effective internal calibration. $^{60,61}$ The common design of the probe has focused on selectivity for individual analytes, but most of the pertinent biological events are related to the interaction of more than one chemical species. It is possible to achieve multiple responses via the simultaneous use of more individual probes. However, the data interpretation will be confounded by the fact that the two separated probes will have different uptake, localization, and emission profiles. An alternative approach is to use a single probe which can respond to two analytes, termed a dual-responsive probe. ${ }^{62}$ Our probe, $\mathrm{HCy}-\mathrm{SeH}$, is a potential candidate for the associated detection of $\mathrm{O}_{2}{ }^{--}$and $\mathrm{Hg}^{2+} . \mathrm{Hg}^{2+}$ can induce the intracellular $\mathrm{O}_{2}{ }^{--}$burst once it invades into the cells. So far, no fluorescent probe can achieve associated detection of $\mathrm{O}_{2}{ }^{\bullet-}$ and $\mathrm{Hg}^{2+}$ including a one-channel or two-channel fluorescent probe, and $\mathrm{HCy}-\mathrm{SeH}$ is the first ratio probe for associated detection of $\mathrm{O}_{2}{ }^{--}$and $\mathrm{Hg}^{2+}$. We consider that the three-channel fluorescent probe $\mathrm{HCy}-\mathrm{SeH}$ will provide excellent detection performance. With the threechannel fluorescent probe $\mathrm{HCy}-\mathrm{SeH}$ we would obtain more new information about the associated changes of $\mathrm{O}_{2}^{--}$and $\mathrm{Hg}^{2+}$ in the complicated processes. Spectroscopic properties and selectivity of the probe are displayed in the Supporting Information.

Associated Detection of $\mathrm{O}_{2}^{--}$and $\mathrm{Hg}^{2+}$ in Chronic Mercurialism Cell Models. Since our probe showed high selectivity and sensitivity for the associated detection of $\mathrm{O}_{2}{ }^{\circ-}$ and $\mathrm{Hg}^{2+}$ in solution, we next assessed the potential utility of the probe for $\mathrm{O}_{2}{ }^{\bullet-}$ and $\mathrm{Hg}^{2+}$ detection in complex biological samples. Before cell imaging, we performed an MTT assay to confirm that our probe had low toxicity. The results revealed that our probe showed low cytotoxicity toward cells (Figure S7). Furthermore, the stability and the reaction kinetics of the probe were performed (Figures S2, S3, and S5) to confirm the feasibility of our probe. Then, we used pretreated HEK 293 cells as the cell model. The cells were washed with minimum essential medium (MEM) for three times to remove the additions before imaging. The three-channel images in Figure la were constructed via fluorescence collection windows: channel $1760-850 \mathrm{~nm}\left(\lambda_{\mathrm{ex}}=635 \mathrm{~nm}\right)$, channel $2 \lambda_{\mathrm{em}}=540-$ $585 \mathrm{~nm}\left(\lambda_{\mathrm{ex}}=405 \mathrm{~nm}\right)$, and channel $3 \lambda_{\mathrm{em}}=585-685 \mathrm{~nm}\left(\lambda_{\mathrm{ex}}\right.$ $=488 \mathrm{~nm})$. The pseudocolor ratio images were obtained as ratio 1, channel 3 versus channel 2 (the images in channel 2 were collected following by the reaction between the probe 
a

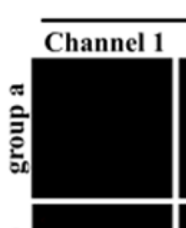

Fluorescence imaging analysis

c Apoptosis analysis $\mathrm{d}_{\mathrm{JC}-1}$
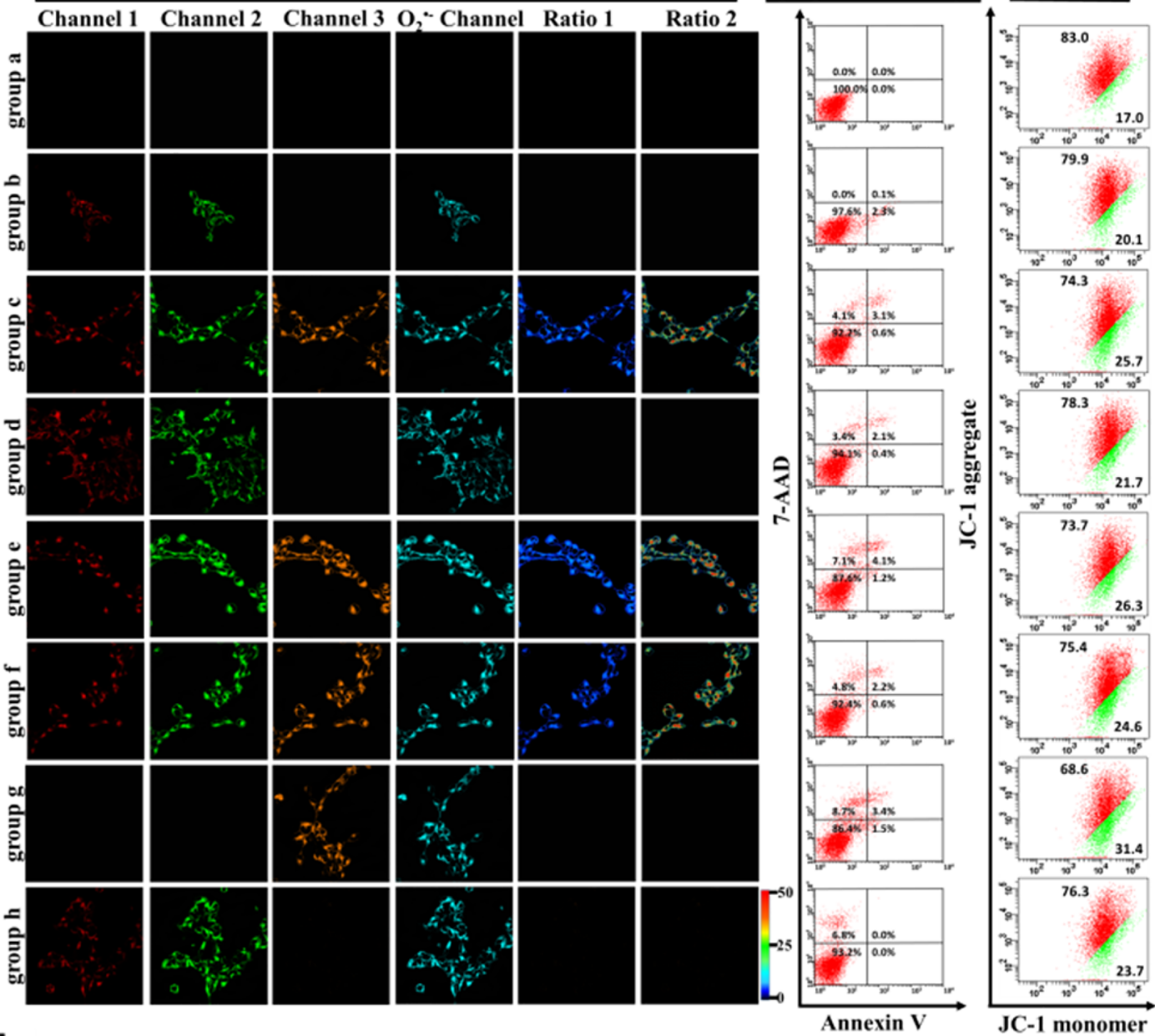

b
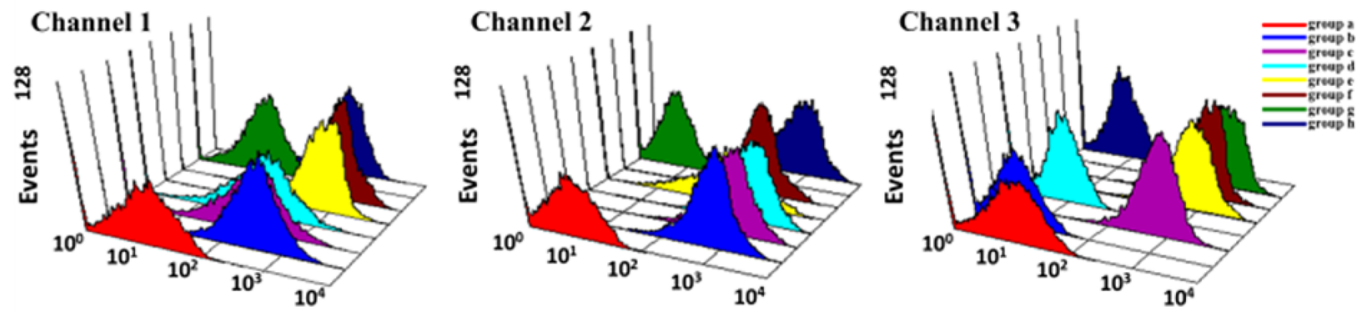

Figure 1. In situ detection of $\mathrm{O}_{2}{ }^{\bullet-}$ and $\mathrm{Hg}^{2+}$ in HEK 293 cells. (a) Fluorescence imaging of the probe for $\mathrm{O}_{2}{ }^{--}$and $\mathrm{Hg}^{2+}$ detection by laser scanning confocal microscopy. Channel $1760-850 \mathrm{~nm}\left(\lambda_{\mathrm{ex}}=635 \mathrm{~nm}\right)$, channel $2 \lambda_{\mathrm{em}}=540-585 \mathrm{~nm}\left(\lambda_{\mathrm{ex}}=405 \mathrm{~nm}\right)$, channel $3 \lambda_{\mathrm{em}}=585-685 \mathrm{~nm}\left(\lambda_{\mathrm{ex}}=\right.$ $488 \mathrm{~nm}), \mathrm{O}_{2}{ }^{-}$channel $\lambda_{\mathrm{em}}=500-530 \mathrm{~nm}\left(\lambda_{\mathrm{ex}}=488 \mathrm{~nm}\right)$; ratio 1, channel 3 vs channel 2; ratio 2, channel 3 vs channel 1. (b) Fluorescence intensity analyzed by flow cytometry. (c) Apoptosis analysis by an Annexin V/7-AAD apoptosis detection kit: viable cells (AnnexinV-/7-AAD-), early apoptosis (AnnexinV+/7-AAD-), late apoptosis (AnnexinV+/7-AAD+), necrosis (AnnexinV-/7-AAD+). (d) $\Delta \Psi_{\mathrm{m}}$ analysis by JC-1. Group a: The cells were incubated with $10 \mu \mathrm{M} \mathrm{HCy}-\mathrm{SeH}$ for $10 \mathrm{~min}$ as control. Group b: The cells were pretreated as described in group a, and then $\mathrm{O}_{2}{ }^{--}(10 \mu \mathrm{M})$ was added for $15 \mathrm{~min}$. Group c: Then, cells in group c were pretreated as described in group b, and $10 \mu \mathrm{M} \mathrm{Hg}{ }^{2+}$ was added for 15 min. Group d: The cells in group d were pretreated as described in group a, and then stimulated with $10 \mathrm{nM}$ PMA for 20 min. Group e: The cells in group e were manipulated as those in group $\mathrm{d}$, and then $10 \mu \mathrm{M} \mathrm{Hg}^{2+}$ was added for $15 \mathrm{~min}$. Group f: Cells were pretreated as described in group a, and then $10 \mu \mathrm{M} \mathrm{Hg}^{2+}$ was added for $30 \mathrm{~min}$. Group g: Cells were pretreated as described in group a, and then $60 \mu \mathrm{M} \mathrm{Hg}^{2+}$ was added for $30 \mathrm{~min}$. Group h: The cells were pretreated with $30 \mu \mathrm{M}$ sodium selenite for $60 \mathrm{~min}$, and then the cells were treated as described in group f.

and the $\mathrm{Hg}^{2+}$, and they are shown in the Supporting Information), and ratio 2 , channel 3 versus channel 1 (the images in channel 1 were collected following by the reaction between the probe and the $\mathrm{Hg}^{2+}$, and they are shown in the Supporting Information). The commercial ROS fluorescent probe 2,7-dichlorodihydrofluorescein diacetate was used for $\mathrm{O}_{2}{ }^{\bullet-}$ detection. The images were obtained in the $\mathrm{O}_{2}{ }^{\bullet-}$ channel: $\lambda_{\mathrm{em}}=500-530 \mathrm{~nm}\left(\lambda_{\mathrm{ex}}=488 \mathrm{~nm}\right)$. The cells in
Figure 1a were divided into eight parallel groups as follows: cells in group a were incubated with $\mathrm{HCy}-\mathrm{SeH}(10 \mu \mathrm{M})$ for $10 \mathrm{~min}$ as control. All the cells in the other groups were pretreated as described in group a. Cells in group b were incubated with $10 \mu \mathrm{M} \mathrm{O}_{2}{ }^{--}$for $15 \mathrm{~min}$. A fluorescence increase could be observed in channel 1 and channel 2, which was attributed to the $\pi$-electron system recovery of the HCy$\mathrm{SeH}$, and the fluorescence in the $\mathrm{O}_{2}{ }^{\bullet-}$ channel was also 


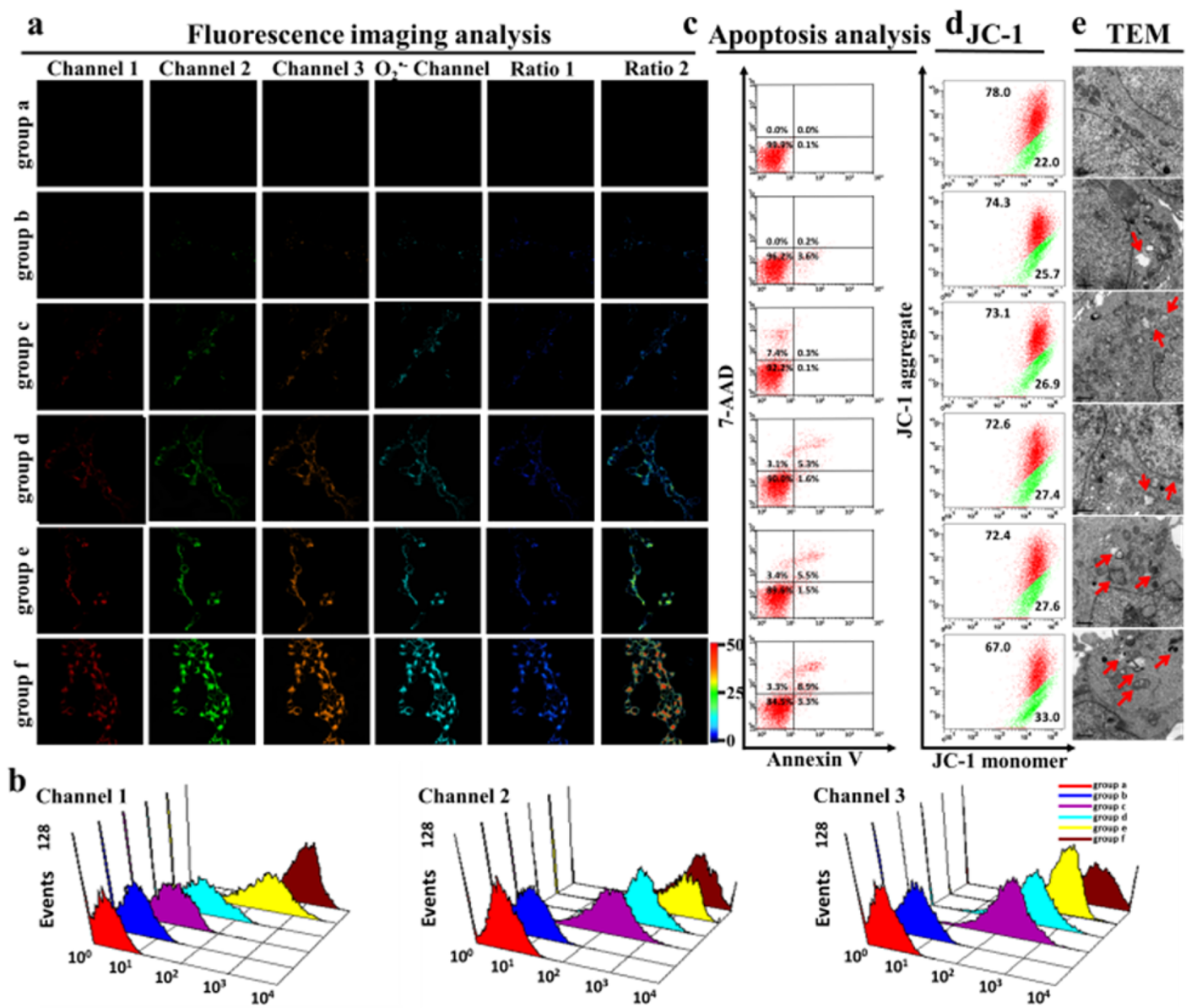

Figure 2. Detection of $\mathrm{O}_{2}{ }^{--}$and $\mathrm{Hg}^{2+}$ in cells with different concentration of $\mathrm{Hg}^{2+}$ stimulation. (a) Laser scanning confocal microscopy analysis. (b) Flow cytometry analysis. (c) Apoptosis analysis by an Annexin V/7-AAD apoptosis detection kit: viable cells (AnnexinV-/7-AAD-), early apoptosis (AnnexinV+/7-AAD-), late apoptosis (AnnexinV+/7-AAD+), necrosis (AnnexinV-/7-AAD+). (d) $\Delta \Psi_{\mathrm{m}}$ analysis by JC-1. (e) TEM observation (scale bars: $1 \mu \mathrm{m}$ ). Concentrations of $\mathrm{Hg}^{2+}$ : group a, $0 \mu \mathrm{M}$; group b, $2 \mu \mathrm{M}$; group c, $4 \mu \mathrm{M}$; group d, $6 \mu \mathrm{M}$; group e, $8 \mu \mathrm{M}$; group f, 10 $\mu \mathrm{M}$.

obtained. Cells in group c were treated as described in group b, and then incubated with $10 \mu \mathrm{M} \mathrm{Hg}^{2+}$ for $15 \mathrm{~min}$. The vivid fluorescence could be observed in all the three channels. The results demonstrated that our probe, $\mathrm{HCy}-\mathrm{SeH}$, could directly associate detect the exogenous $\mathrm{O}_{2}{ }^{\bullet-}$ and $\mathrm{Hg}^{2+}$. Cells in group $\mathrm{d}$ were treated as described in group a, and then phorbol myristate acetate (PMA, $10 \mathrm{nM}$ ) was added for $20 \mathrm{~min}$ to induce endogenous $\mathrm{O}_{2}{ }^{\bullet-}$ generation. The fluorescence signals were collected from channel 1 , channel 2 , and the $\mathrm{O}_{2}{ }^{\bullet-}$ channel, which indicated the burst of endogenous $\mathrm{O}_{2}{ }^{\bullet-}$. The HEK 293 cells in group e were treated as described in group d, and then $10 \mu \mathrm{M} \mathrm{\textrm {Hg } ^ { 2 + }}$ was added. A strong fluorescence enhancement was observed in channel 1, channel 2, channel 3, and the $\mathrm{O}_{2}{ }^{--}$channel. As is known to all, $\mathrm{Hg}^{2+}$ has cytotoxicity, and it can induce the burst of $\mathrm{O}_{2}{ }^{--}$in cells. Cells in group $\mathrm{f}$ were incubated with $10 \mu \mathrm{M} \mathrm{Hg}^{2+}$ for $30 \mathrm{~min}$. As expected, strong fluorescence was observed in the three channels as well as the $\mathrm{O}_{2}{ }^{--}$channel. The results confirmed that $\mathrm{Hg}^{2+}$ could lead to the overproduction of intracellular $\mathrm{O}_{2}{ }^{\bullet-}$. Then, cells in group g were treated with $60 \mu \mathrm{M} \mathrm{Hg}^{2+}$ for $30 \mathrm{~min}$. There was no fluorescence to be collected in channel 1 and channel 2, while channel 3 and the $\mathrm{O}_{2}{ }^{\bullet-}$ channel provided strong fluorescence. The phenomenon was attributed to that $\mathrm{Hg}^{2+}$ induced $\mathrm{O}_{2}{ }^{--}$would trigger $\mathrm{HCy}-\mathrm{SeH}$ to $\mathrm{Cy}-\mathrm{SeH}$. However, the high concentration of $\mathrm{Hg}^{2+}$ could quickly transform all the probe $\mathrm{Cy}-\mathrm{SeH}$ to Keto-Cy, and we could not capture the signals in channel 1 and channel 2 . Therefore, bright fluorescence was collected only in channel 3 and the $\mathrm{O}_{2}{ }^{--}$ channel. Sodium selenite has been considered to be a detoxicant for $\mathrm{Hg}^{2+}$; it can protect cells and organisms against the mercury poisoning via selenium-mercury antagonism. ${ }^{63}$ Thus, the cells in group $\mathrm{h}$ were incubated with $30 \mu \mathrm{M}$ sodium selenite for $60 \mathrm{~min}$, and then the cells were treated as described in group $f$. Bright fluorescence images were collected in the channel 1 , channel 2 , and the $\mathrm{O}_{2}{ }^{--}$channel in addition to channel 3 . We reasoned that $\mathrm{Hg}^{2+}$ could be efficaciously antagonized with selenium. However, $\mathrm{Hg}^{2+}$-induced overproduction of $\mathrm{O}_{2}{ }^{--}$lasted, which suggested that cell damage caused by $\mathrm{Hg}^{2+}$ was persistent. Cells were difficult to self-repair within a short time, even though mercury antagonist was used. However, sodium selenite terminated the cytotoxicity of $\mathrm{Hg}^{2+}$, and it still played cytoprotective roles in cells. These results confirm our hypothesis at the cellular level. That is, the oxidative stress cause by $\mathrm{Hg}^{2+}$ leads to organism damage. Furthermore, flow cytometry analysis has been widely used in cellular quantitative analysis due to its high precision for abundant samples analysis; thus, the fluorescence responses are confirmed by flow cytometry assay (Figure $1 \mathrm{~b}$ ). The results from laser scanning confocal microscopy and flow cytometry were well-consistent, indicating that our probe could be 
applied for the associated detection of $\mathrm{O}_{2}{ }^{\bullet-}$ and $\mathrm{Hg}^{2+}$ in living cells.

The cell apoptosis analysis was performed with an Annexin $\mathrm{V} / 7-\mathrm{AAD}$ apoptosis detection kit (Figure 1c). The apoptosis rates (including necrosis) had been ordered as $\mathrm{g}(13.6 \%)>\mathrm{e}$ $(12.4 \%)>\mathrm{c}(7.8 \%)>\mathrm{f}(7.6 \%)>\mathrm{h}(6.8 \%)>\mathrm{d}(5.9 \%)>\mathrm{b}$ $(2.4 \%)>a(0.0 \%)$. Compared to the normal cells, cells in the early apoptosis stage have much difference in the mitochondrial membrane potential $\left(\Delta \Psi_{\mathrm{m}}\right)$. The decreasing red/green fluorescence intensity ratio revealed the increase of cell apoptosis. We utilized the J-aggregate-forming lipophilic cation $5,5^{\prime}, 6,6^{\prime}$-tetrachloro- $1,1^{\prime}, 3,3^{\prime}$-tetraethylbenzimidazolylcarbocyanine iodide (JC-1) to further investigate the $\mathrm{Hg}^{2+}$-induced cytotoxicity. As illustrated in Figure 1d, the red/green fluorescence intensity ratio could be ordered as $\mathrm{g}$ $(68.6 \%: 31.4 \%)<$ e $(73.7 \%: 26.3 \%)<c(74.3 \%: 25.7 \%)<\mathrm{f}$ $(75.4 \%: 24.6 \%)<\mathrm{h}(76.3 \%: 23.7 \%)<\mathrm{d}(78.3 \%: 21.7 \%)<\mathrm{b}$ (79.9\%:20.1\%) < a (83.0\%:17.0\%). The results were highly consistent. Our assay revealed that $\mathrm{Hg}^{2+}$ had severe cytotoxicity and could cause cell apoptosis and necrosis. The utilization of sodium selenite could rapidly antagonize mercury toxicity in cells, but it could not control the burst of $\mathrm{O}_{2}{ }^{--}$, which still destroyed the cells with oxidative stress. Therefore, we suggested that, when using reagents to deal with mercury poisoning, we should also pay attention to the control of complication, such as the excessive production of $\mathrm{O}_{2}{ }^{\bullet-}$.

We next established the chronic mercurialism models with HEK 293 cells. The cells were simulated with different concentrations of $\mathrm{Hg}^{2+}$ (groups b, c, d, e, and f: 2, 4, 6, 8, and $10 \mu \mathrm{M}$, respectively) for $12 \mathrm{~h}$ to examine the associated response of $\mathrm{O}_{2}{ }^{--}$and $\mathrm{Hg}^{2+}$. Then, the fluorescence images were observed with laser scanning confocal microscopy. As displayed in Figure 2a, the HEK 293 cells in group a were incubated with $10 \mu \mathrm{M} \mathrm{HCy}-\mathrm{SeH}$ for $10 \mathrm{~min}$ as the control. There was no fluorescence to be observed. With the concentration of $\mathrm{Hg}^{2+}$ increased (groups $\mathrm{b}-\mathrm{f}$ ), the four channels, channel 1 , channel 2 , channel 3 , and the $\mathrm{O}_{2}{ }^{\bullet-}$ channel, gradually emitted bright fluorescence. Also, the fluorescence ratio intensity in ratio 1 and ratio 2 increased. The fluorescence changes in the chronic mercurialism models were confirmed by flow cytometry (Figure $2 b$ ), and the cell statistical results were well-consistent with those of laser scanning confocal microscopy. These results confirmed that our probe was an efficient chemical tool for the associated detection of $\mathrm{O}_{2}{ }^{--}$and $\mathrm{Hg}^{2+}$ in cells. Due to the cytotoxicity of $\mathrm{Hg}^{2+}$, we next checked cell apoptosis in these cell models. The apoptosis rates of the cells were assessed employing an Annexin V/7-AAD apoptosis detection kit (Figure 2c) and JC1 (Figure 2d). In groups $\mathrm{a}-\mathrm{f}$, the cell apoptosis rates (including necrosis) were $0.1 \%, 3.8 \%, 7.8 \%, 10.0 \%, 10.4 \%$, and $15.5 \%$, respectively; the red/green fluorescence intensity ratios in groups a-f were $78.0 \%: 22.0 \%, 74.3 \%: 25.7 \%$, $73.1 \%: 26.9 \%$, $72.6 \%: 27.4 \%$, $72.4 \%: 27.6 \%, 67.0 \%: 33.0 \%$. The results of apoptosis analysis demonstrated that the cell apoptosis rate highly depended on the concentrations of $\mathrm{Hg}^{2+}$. The degrees of cell damage were sorted in an order of $\mathrm{f}>$ $\mathrm{e}>\mathrm{d}>\mathrm{c}>\mathrm{b}>\mathrm{a}$. TEM was used to directly observe the changes of subcellular organelles morphology for evaluating cell damage (Figure 2e). The control cells in group a exhibited continuous and clear nuclear membrane and mitochondria ridge. With the increase of $\mathrm{Hg}^{2+}$ the degree of cell injury became severe (groups $b-f$ in Figure 2e). The nuclear membrane and the mitochondrial ridge gradually turned vague, also with mitochondrial swelling, and the density of intracellular cavitation increased. These results further confirmed the cytotoxicity of $\mathrm{Hg}^{2+}$. Our probe, $\mathrm{HCy}-\mathrm{SeH}$, was suitable for the associated detection of $\mathrm{O}_{2}{ }^{--}$and $\mathrm{Hg}^{2+}$ in the chronic mercurialism cell models, and $\mathrm{HCy}-\mathrm{SeH}$ is potentially exploited as an auxiliary diagnostic tool for the treatment of mercury poisoning. The fluorescence images of the cells in Figure 1 and Figure 2 after the probe reacted with $\mathrm{Hg}^{2+}$ are shown in Figures S8 and S10. The bright-field images of Figure 1 and Figure 2 are shown in Figures S9 and S11.

Visualization of $\mathrm{O}_{2}{ }^{--}$and $\mathrm{Hg}^{2+}$ in Mice. Since the NIR fluorescence can deeply penetrate tissue, protect samples from photodamage, and avoid autofluorescence, we applied our NIR fluorescent probe $\mathrm{HCy}-\mathrm{SeH}$ for in vivo imaging of $\mathrm{O}_{2}{ }^{--}$and $\mathrm{Hg}^{2+}$. The in vivo imaging assays were performed with an in vivo imaging system. The fluorescence images were obtained from three fluorescence collection windows: channel $1 \lambda_{\mathrm{ex}}=$ $740 \mathrm{~nm}$ with filter $790 \mathrm{~nm}$, channel $2 \lambda_{\mathrm{ex}}=420 \mathrm{~nm}$ with filter $570 \mathrm{~nm}$, and channel $3 \lambda_{\text {ex }}=520 \mathrm{~nm}$ with filter $620 \mathrm{~nm}$. The mice in Figure $3 \mathrm{a}$ were injected with $\mathrm{HCy}-\mathrm{SeH}(100 \mu \mathrm{M}, 100$

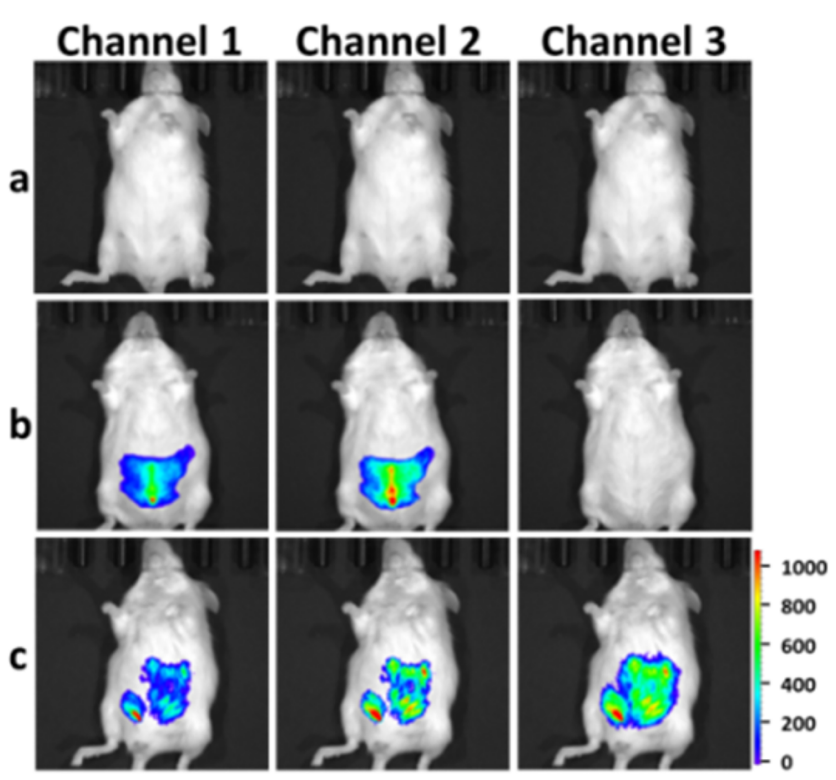

Figure 3. In vivo imaging of $\mathrm{O}_{2}^{--}$and $\mathrm{Hg}^{2+}$ in the peritoneal cavity of mice $\mathrm{BALB} / \mathrm{c}$. (a) Mice were ip cavity injected with $\mathrm{HCy}-\mathrm{SeH}$ (100 $\mu \mathrm{M}, 100 \mu \mathrm{L}$ in 1:99 DMSO/saline v/v) for $30 \mathrm{~min}$. (b) Mice were pretreated with $100 \mu \mathrm{M} \mathrm{HCy}-\mathrm{SeH}(100 \mu \mathrm{L}$ in 1:99 DMSO/saline v/ v) for $30 \mathrm{~min}$, and then ip injected with PMA $(100 \mathrm{nM}, 100 \mu \mathrm{L}$ in 1:99 DMSO/saline $\mathrm{v} / \mathrm{v}$ ) for $30 \mathrm{~min}$. (c) Mice were pretreated as described in panel a, and then the mice were ip cavity injected with $\mathrm{Hg}^{2+}(30 \mu \mathrm{M}, 100 \mu \mathrm{L}$ in 1:99 water/saline $\mathrm{v} / \mathrm{v})$ for $1 \mathrm{~h}$.

$\mu \mathrm{L}$, in 1:99 DMSO/saline $\mathrm{v} / \mathrm{v}$ ) for $30 \mathrm{~min}$ as control. There was no fluorescence to be observed in Figure 3a. The mice in Figure $3 \mathrm{~b}$ were pretreated with $\mathrm{HCy}-\mathrm{SeH}(100 \mu \mathrm{M}, 100 \mu \mathrm{L}$, in 1:99 DMSO/saline, v/v) for $30 \mathrm{~min}$, and then PMA (100 $\mathrm{nM}, 100 \mu \mathrm{L}$ in $1: 99 \mathrm{DMSO} /$ saline $\mathrm{v} / \mathrm{v}$ ) was injected for 30 min to induce $\mathrm{O}_{2}{ }^{\bullet-}$ generation. The mice in Figure $3 \mathrm{~b}$ showed clear fluorescence in channel 1 and channel 2 . The mice in Figure $3 \mathrm{c}$ were preinjected with $\mathrm{HCy}-\mathrm{SeH}(100 \mu \mathrm{M}, 100 \mu \mathrm{L}$ in $1: 99 \mathrm{DMSO} /$ saline $\mathrm{v} / \mathrm{v})$, and then $\mathrm{Hg}^{2+}(30 \mu \mathrm{M}, 100 \mu \mathrm{L}$ in $1: 99$ water/saline $\mathrm{v} / \mathrm{v}$ ) was injected for $1 \mathrm{~h}$ to induce $\mathrm{O}_{2}{ }^{\bullet-}$ burst. Bright fluorescence was collected in the three channels due to the associated response of $\mathrm{O}_{2}{ }^{\bullet-}$ and $\mathrm{Hg}^{2+}$. These results 

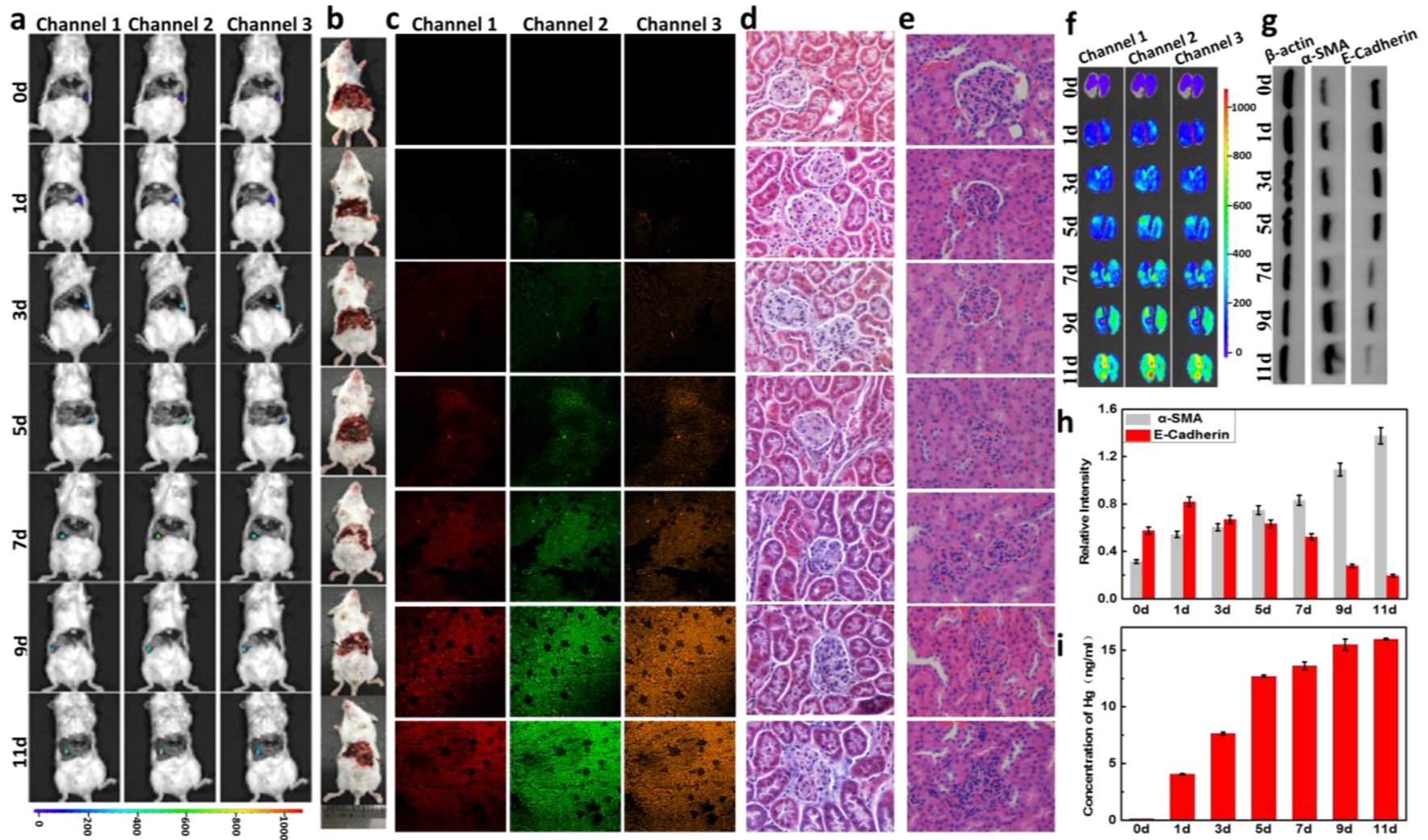

Figure 4. Detection of $\mathrm{O}_{2}^{\bullet-}$ and $\mathrm{Hg}^{2+}$ in mice models of chronic mercurialism. (a) Fluorescence imaging of the kidney in the mice of chronic mercurialism through orthotopic injection assay. (b) The details of the organ ligation were obtained from the camera. (c) Fluorescence imaging of the kidney sections. The tissue sections were stained with $\mathrm{HCy}-\mathrm{SeH}(10 \mu \mathrm{M})$ for $10 \mathrm{~min}$. (d) Masson's trichrome stain of the kidney sections. (e) H\&E staining of the kidney sections from normal and model mice. (f) Fluorescence imaging of the kidneys from the mice in panel a. (g) Western blot analysis of $\alpha$-SMA and E-cadherin. (h) The relative intensity analysis of $\alpha$-SMA and E-cadherin by ImageJ software. (i) Detection of Hg ${ }^{2+}$ in kidneys by ICPMS.

demonstrated that the probe $\mathrm{HCy}-\mathrm{SeH}$ could be used to combine detect $\mathrm{O}_{2}{ }^{\bullet-}$ and $\mathrm{Hg}^{2+}$ in vivo.

Associated Visualization of $\mathrm{O}_{2}{ }^{--}$and $\mathrm{Hg}^{2+}$ in the Chronic Mercurialism Mice Models. Among all of the organs, the kidney is the most susceptible organ toward mercury toxicity due to the dominant accumulation of $\mathrm{Hg}^{2+}$ in the kidney. ${ }^{6}$ Therefore, we try to apply $\mathrm{HCy}-\mathrm{SeH}$ to the $\mathrm{O}_{2}{ }^{\bullet-}$ and $\mathrm{Hg}^{2+}$ associated detection in mice models of chronic mercurialism. The mice models of chronic mercurialism in Figure $4 \mathrm{a}$ were given mercury chloride $(18 \mathrm{mg} / \mathrm{kg}$ in saline/ day) orally by gavage with different days (1, 3, 5, 7, 9, 11 days). The mice in group 0 day were given saline orally by gavage as control. The detailed steps are recorded in the Supporting Information. Then, the fluorescence images were obtained with three fluorescence collection windows: channel $1 \lambda_{\mathrm{ex}}=740 \mathrm{~nm}$ with filter $790 \mathrm{~nm}$, channel $2 \lambda_{\text {ex }}=420 \mathrm{~nm}$ with filter $570 \mathrm{~nm}$, and channel $3 \lambda_{\text {ex }}=520 \mathrm{~nm}$ with filter $620 \mathrm{~nm}$. The probe $\mathrm{HCy}-\mathrm{SeH}(10 \mu \mathrm{M}, 10 \mu \mathrm{L}$, in 1:99 $\mathrm{DMSO} /$ saline $\mathrm{v} / \mathrm{v})$ was injected into the kidney through the renal artery for the associated detection of $\mathrm{O}_{2}{ }^{\bullet-}$ and $\mathrm{Hg}^{2+}$. Then, the renal artery and renal vein were ligated as quickly as possible. Finally, with the time extension of mercury stress, the accumulating $\mathrm{Hg}^{2+}$ in the kidney would increase the levels of $\mathrm{O}_{2}{ }^{--}$; thus, the fluorescence signals from channel 1 and channel 2 increased gradually. Furthermore, the fluorescence signals from channel 3 were increasing, indicting the accumulation of $\mathrm{Hg}^{2+}$ in kidney (Figure 4a). The kidneys were dissected from chronic mercurialism mice in Figure $4 \mathrm{a}$ to acquire the ex vivo fluorescence images. As shown in Figure 4f, the increase of fluorescence signals from channel 1 and channel 2 indicated the rising concentrations of $\mathrm{O}_{2}{ }^{\bullet-}$. The fluorescence signals from channel 3 implied that the $\mathrm{Hg}^{2+}$ gradually accumulated in the kidney. We also obtained the fresh tissue sections from fresh kidneys for quick detection via fluorescence imaging. As shown in Figure $4 c$, the changes of fluorescence were consistent with those of Figure 4 , parts a and $f$, and the bright-field images of Figure 4, parts $\mathrm{c}$ and $\mathrm{f}$, are shown in Figures S12 and S13.

Chronic mercurialism can cause epithelial-mesenchymal transition (EMT), which is a pathology with a polarized epithelial cell undertaking a mesenchymal cell phenotype through a series of biological processes. ${ }^{64}$ The tissue sections of kidney from normal and model mice in Figure $4 \mathrm{a}$ were stained by Masson's trichrome stain and H\&E (hematoxylin and eosin), respectively. As shown in Figure 4, parts d and e, long-term mercury stress in the kidney could result in EMT, and finally lead to renal interstitial fibrosis. When stained by Masson's trichrome, the collagenous fiber showed in blue color, which was the histological examination for interstitial fibrosis. There were normal collagenous fibers in the control group (Figure 4d), but the collagenous fiber increased gradually along with the days of giving mercury chloride orally by gavage. The pathogenesis was also confirmed by $\mathrm{H} \& \mathrm{E}$ (Figure 4e). The glomerulus of the control group was shown as integral and clear profiles, and the nuclei were regular. However, mercury stress during the 11 days led to an 

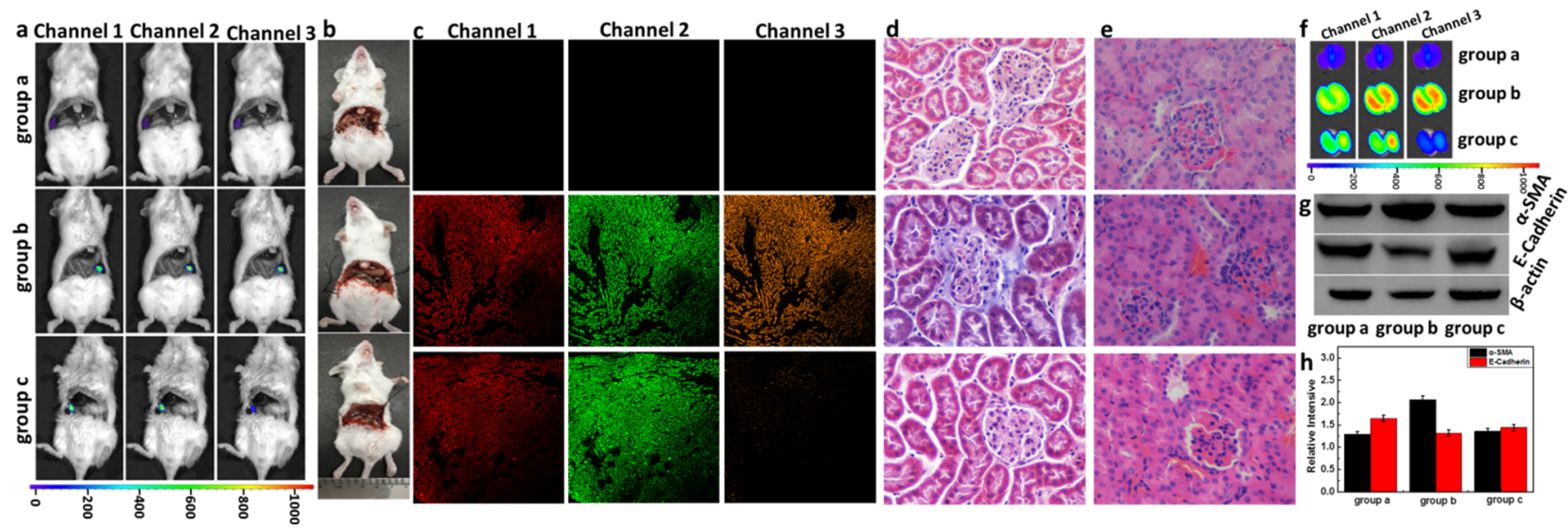

Figure 5. Detection of $\mathrm{O}_{2}^{--}$and $\mathrm{Hg}^{2+}$ in mice models. (a) Fluorescence imaging of kidneys through orthotopic injection assay. (b) The details of the organ ligation were obtained from the camera. (c) Fluorescence imaging of the kidney sections from normal and model mice. (d) Masson's trichrome stain of the kidney sections from normal and model mice. (e) H\&E staining of the kidney sections from the mice in panel a. (f) Fluorescence imaging of the kidneys from the mice in panel a. (g) Western blot analysis of $\alpha$-SMA and E-cadherin. (h) The relative intensity analysis of $\alpha$-SMA and E-cadherin by ImageJ software.

incomplete glomerulus profile, which could be attributed to the interstitial fibrosis systemic sclerosis, and then led to the glomerulus distortion. During the EMT process, the level of fibroblast-specific protein $\alpha$-SMA would increase, and the level of protein E-cadherin which was expressed in epithelial cells would decrease. Due to the kidney damage stimulated by $\mathrm{Hg}^{2+}$ primarily in the cortex of the kidney, ${ }^{65}$ the protein was extracted from the cortex of the kidney. We performed Western blot assay to investigate the level changes of $\alpha$-SMA and E-cadherin because the two proteins had been regarded as pathological features of EMT. As shown in Figure 4g, $\alpha$-SMA was up-regulated and the E-cadherin was down-regulated along with the mercury stress time. It was worth noting that the level of E-cadherin increased. The reason remains to be further studied. The relative quantitative analysis of $\alpha$-SMA and Ecadherin was determined by the ImageJ software, and the results are shown in Figure $4 \mathrm{~h}$. The content of $\mathrm{Hg}^{2+}$ in the tissue of the kidney was also determined using inductively coupled plasma mass spectrometry (ICPMS) (Figure 4i). The results demonstrated that $\mathrm{Hg}^{2+}$ could accumulate in the kidney. The probe could be used to detect the level of $\mathrm{Hg}^{2+}$ in the blood and urine of a mercury poisoning patient. The result was confirmed by atomic absorption spectrometry (AAS, Figure S16).

Sodium selenite had been used as an antagonist for the treatment of mercury poisoning. We next attempted to test the efficacy of sodium selenite on the treatment of chronic mercurialism. The mice in Figure 5a were divided into three groups: The mice in group a were given normal saline $(0.2$ $\mathrm{mL} /$ day) for 11 days as the control. The mice in group $\mathrm{b}$ were given mercury chloride $(18 \mathrm{mg} / \mathrm{kg}$ in $0.2 \mathrm{~mL}$ saline) for 11 days as the model group. The mice in group $\mathrm{c}$ were given mercury chloride $(18 \mathrm{mg} / \mathrm{kg})$ and sodium selenite $(0.5 \mathrm{mg} / \mathrm{kg})$ for 11 days as the therapy group. The mice in group a did not show fluorescence (Figure 5, parts a, c, and f). The mice in group $b$ provided bright fluorescence from the three channels, indicating our probe had detected $\mathrm{O}_{2}{ }^{--}$and $\mathrm{Hg}^{2+}$. Due to the antagonism between selenium and mercury, only channel 1 and channel 2 gave obvious fluorescence in the mice of group c. Herein, we emphasized that even if mercury chloride and sodium selenite were utilized at the same time, it could also cause a severe burst of $\mathrm{O}_{2}^{\bullet-}$ in the kidney. The bright-field images of Figure 5, parts c and f, are shown in Figures S14 and S15. The fresh tissue sections coming from the mice in groups $a-c$ were stained with Masson's trichrome and H\&E, respectively (Figure 5, parts $\mathrm{d}$ and e). The images from group a showed the normal morphology of glomeruli, while severe renal fibrosis was observed in group b. The histological sections of the treatment group showed that sodium selenite could well antagonize mercury toxicity. The Western blot was also performed to test the level changes of $\alpha$-SMA and Ecadherin (Figure 5, parts g and h). In the therapy group, the $\alpha$ SMA was down-regulated and the E-cadherin was up-regulated compared to the model group. The results also showed the utilization of sodium selenite to treat chronic mercurialism. However, our probe, $\mathrm{HCy}-\mathrm{SeH}$, further offered an important information that, although sodium selenite antagonized $\mathrm{Hg}^{2+}$, it could not eliminate the outbreak of $\mathrm{O}_{2}^{\bullet-}$ caused by mercury poisoning. We proposed that the active sites of the intracellular antioxidant system were mainly presented as mercapto or selenol groups. The entrance of $\mathrm{Hg}^{2+}$ destroyed the active sites of these enzymes. Even if $\mathrm{Hg}^{2+}$ had been antagonized by sodium selenite, it was difficult to recover the antioxidant functions of antioxidant enzymes in a short time. Therefore, we recommend that one should pay attention to the damage caused by oxidative stress during the treatment of mercury poisoning.

\section{CONCLUSION}

In conclusion, to confirm the proposed mechanism that the oxidative stress cause by $\mathrm{Hg}^{2+}$ leads to poor prognosis of the mercury poisoning, we designed and synthesized a NIR threechannel fluorescent probe, $\mathrm{HCy}-\mathrm{SeH}$, for the associated detection of $\mathrm{O}_{2}{ }^{\bullet-}$ and $\mathrm{Hg}^{2+}$ in cells and mice models of chronic mercury poisoning. When used for the detection, the threechannel responses provided ratio fluorescence signals which can eliminate the interference induced by the uneven loading or the inhomogeneous distribution. The probe exhibits high selectivity and sensitivity toward the associated detection of $\mathrm{O}_{2}^{\bullet-}$ and $\mathrm{Hg}^{2+}$. The fluorescence imaging and the flow cytometry analysis demonstrate that the probe can be used to in situ detect $\mathrm{O}_{2}{ }^{--}$and $\mathrm{Hg}^{2+}$ in HEK 293 cell models. The 
results demonstrate that the accumulation of $\mathrm{Hg}^{2+}$ will interrupt the cellular antioxidant system and induce the overproduction of $\mathrm{O}_{2}{ }^{\bullet-}$. We successfully applied the probe to the utilization in mice models of chronic mercurialism. The results confirm that mercury poisoning can cause kidney damage and lead to renal fibrosis. We employed sodium selenite to antagonize $\mathrm{Hg}^{2+}$ in vivo. Although this antagonist can efficaciously relieve the chronic mercurialism, it cannot reduce the high level of $\mathrm{O}_{2}{ }^{\bullet-}$. Therefore, the organism damage caused by $\mathrm{Hg}^{2+}$ may continue in a long term. These results highlight that our probe can be used as a powerful tool for $\mathrm{O}_{2}{ }^{--}$and $\mathrm{Hg}^{2+}$ associated detection in vitro and in vivo. We believe that our probe can be a benefit for clinical surgery preevaluation.

\section{ASSOCIATED CONTENT}

\section{S Supporting Information}

The Supporting Information is available free of charge on the ACS Publications website at DOI: 10.1021/acs.analchem.8b01442.

More experimental materials and details, synthesis steps, and characterization of compounds (PDF)

\section{AUTHOR INFORMATION}

\section{Corresponding Authors}

*E-mail: fbyu@yic.ac.cn.

*E-mail: 1xchen@yic.ac.cn.

\section{ORCID}

Fabiao Yu: 0000-0003-0073-6299

Lingxin Chen: 0000-0002-3764-3515

\section{Notes}

The authors declare no competing financial interest.

\section{ACKNOWLEDGMENTS}

We thank the National Nature Science Foundation of China (nos. 21575159, 21775162, 41776110, 41506126, and 21405172), the program of Youth Innovation Promotion Association, CAS (Grant 2015170), the Instrument Developing Project of the Chinese Academy of Sciences (YZ201662), and the Key Laboratory of Sensor Analysis of Tumor Marker, Ministry of Education, Qingdao University of Science and Technology (Grant SATM201705).

\section{REFERENCES}

(1) Chen, X.; Pradhan, T.; Wang, F.; Kim, J. S.; Yoon, J. Chem. Rev. 2012, 112, 1910-1956.

(2) Bera, K.; Das, A. K.; Nag, M.; Basak, S. Anal. Chem. 2014, 86, 2740-2746.

(3) Du, J.; Fan, J.; Peng, X.; Sun, P.; Wang, J.; Li, H.; Sun, S. Org. Lett. 2010, 12, 476-479.

(4) Jiang, J.; Liu, W.; Cheng, J.; Yang, L.; Jiang, H.; Bai, D.; Liu, W. Chem. Commun. 2012, 48, 8371-8373.

(5) Ko, S. K.; Yang, Y. K.; Tae, J.; Shin, I. J. Am. Chem. Soc. 2006, 128, 14150-14155.

(6) Sin, Y. M.; Lim, Y. F.; Wong, M. K. B. Bull. Environ. Contam. Toxicol. 1983, 31, 605-612.

(7) Zhang, W.; Li, P.; Yang, F.; Hu, X.; Sun, C.; Zhang, W.; Chen, D.; Tang, B. J. Am. Chem. Soc. 2013, 135, 14956.

(8) Dickinson, B. C.; Chang, C. J. Nat. Chem. Biol. 2011, 7, 504.

(9) Chen, X.; Tian, X.; Shin, I.; Yoon. Chem. Soc. Rev. 2011, 40, $4783-4804$
(10) Stacchiotti, A.; Morandini, F.; Bettoni, F.; Schena, I.; Lavazza, A.; Grigolato, P. G.; Apostoli, P.; Rezzani, R.; Aleo, M. F. Toxicology 2009, 264, 215-224.

(11) Hayes, J. D.; Flanagan, J. U.; Jowsey, I. R. Annu. Rev. Pharmacol. Toxicol. 2005, 45, 51-88.

(12) Goering, P. L.; Morgan, D. L.; Ali, S. F. J. J. Appl. Toxicol. 2002, 22, $167-172$.

(13) Winterbourn, C. C. Nat. Chem. Biol. 2008, 4, 278.

(14) Brownlee, M. Nature 2001, 414, 813.

(15) Cai, H.; Harrison, D. G. Circ. Res. 2000, 87, 840.

(16) Mattson, M. P. Nature 2004, 430, 631.

(17) Zhang, J.; Li, C.; Zhang, R.; Zhang, F.; Liu, W.; Liu, X.; Lee, S. M. Y.; Zhang, H. Chem. Commun. 2016, 52, 2679.

(18) Nilsson, U. A.; Haraldsson, G.; Bratell, S.; Sorensen, V.; Akerlund, S.; Pettersson, S.; Schersten, T.; Jonsson, O. Acta Physiol. Scand. 1993, 147, 263-270.

(19) Gao, X.; Feng, G.; Manghnani, P. N.; Hu, F.; Jiang, N.; Liu, J.; Liu, B.; Sun, J. Z.; Tang, B. Z. Chem. Commun. 2017, 53, 1653-1656.

(20) dos Santos, J. S.; de la Guardia, M.; Pastor, A.; dos Santos, M. L. P. Talanta 2009, 80, 207-211.

(21) Feng, L.; Chen, Z. Sens. Actuators, B 2007, 122, 600-604.

(22) Gao, M.; Yu, F.; Chen, H.; Chen, L. Anal. Chem. 2015, 87, $3631-3638$

(23) Han, X.; Yu, F.; Song, X.; Chen, L. Chem. Sci. 2016, 7, 50985107.

(24) Xu, Z.; Baek, K. H.; Kim, H. N.; Cui, J.; Qian, X.; Spring, D. R.; Shin, I.; Yoon, J. J. Am. Chem. Soc. 2010, 132, 601-610.

(25) Xu, Z.; Singh, N. J.; Lim, J.; Pan, J.; Kim, H. N.; Park, S.; Kim, K. S.; Yoon, J. J. Am. Chem. Soc. 2009, 131, 15528.

(26) Gao, M.; Yu, F.; Lv, C.; Choo, J.; Chen, L. Chem. Soc. Rev. 2017, 46, 2237-2271.

(27) Hu, J. J.; Wong, N. K.; Ye, S.; Chen, X.; Lu, M. Y.; Zhao, A. Q.; Guo, Y.; Ma, A. C. H.; Leung, A. Y. H.; Shen, J.; Yang, D. J. Am. Chem. Soc. 2015, 137, 6837-6843.

(28) Lu, D.; Zhou, L.; Wang, R.; Zhang, X. B.; He, L.; Zhang, J.; Hu, X.; Tan, W. Sens. Actuators, B 2017, 250, 259-266.

(29) Li, R. Q.; Mao, Z. Q.; Rong, L.; Wu, N.; Lei, Q.; Zhu, J. Y.; Zhuang, L.; Zhang, X. Z.; Liu, Z. H. Biosens. Bioelectron. 2017, 87, 7380.

(30) Li, P.; Zhang, W.; Li, K.; Liu, X.; Xiao, H.; Zhang, W.; Tang, B. Anal. Chem. 2013, 85, 9877-9881.

(31) Chen, X.; Wang, F.; Hyun, J. Y.; Wei, T.; Qiang, J.; Ren, X.; Shin, I.; Yoon, J. Chem. Soc. Rev. 2016, 45, 2976.

(32) Ding, J.; Li, H.; Wang, C.; Yang, J.; Xie, Y.; Peng, Q.; Li, Q.; Li, Z. ACS Appl. Mater. Interfaces 2015, 7, 11369-11376.

(33) Song, C.; Yang, W.; Zhou, N.; Qian, R.; Zhang, Y.; Lou, K.; Wang, R.; Wang, W. Chem. Commun. 2015, 51, 4443.

(34) Zhang, X.; Xiao, Y.; Qian, X. Angew. Chem., Int. Ed. 2008, 47, $8025-8029$.

(35) Hu, B.; Hu, L. L.; Chen, M. L.; Wang, J. H. Biosens. Bioelectron. 2013, 49, 499-505.

(36) Gong, Y. J.; Zhang, X. B.; Zhang, C. C.; Luo, A. L.; Fu, T.; Tan, W.; Shen, G. L.; Yu, R. Q. Anal. Chem. 2012, 84, 10777-10784.

(37) Ando, S.; Koide, K. J. Am. Chem. Soc. 2011, 133, 2556.

(38) Song, F.; Watanabe, S.; Floreancig, P. E.; Koide, K. J. Am. Chem. Soc. 2008, 130, 16460-16461.

(39) Diaz de Grenu, B.; Garcia Calvo, J.; Cuevas, J.; Garcia Herbosa, G.; Garcia, B.; Busto, N.; Ibeas, S.; Torroba, T.; Torroba, B.; Herrera, A.; Pons, S. Chem. Sci. 2015, 6, 3757-3764.

(40) Li, L.; Li, Z.; Shi, W.; Li, X.; Ma, H. Anal. Chem. 2014, 86, 6115-6120.

(41) Gong, Y. J.; Zhang, X. B.; Mao, G. J.; Su, L.; Meng, H. M.; Tan, W.; Feng, S.; Zhang, G. Chem. Sci. 2016, 7, 2275-2285.

(42) Yuan, L.; Lin, W.; Zheng, K.; He, L.; Huang, W. Chem. Soc. Rev. 2013, 42, 622-661.

(43) Zhao, C.; Zhang, X.; Li, K.; Zhu, S.; Guo, Z.; Zhang, L.; Wang, F.; Fei, Q.; Luo, S.; Shi, P.; Tian, H.; Zhu, W. H. J. Am. Chem. Soc. 2015, 137, 8490-8498. 
(44) Yuan, L.; Lin, W.; Yang, Y. Chem. Commun. 2011, 47, 62756277.

(45) Fan, J.; Sun, W.; Hu, M.; Cao, J.; Cheng, G.; Dong, H.; Song, K.; Liu, Y.; Sun, S.; Peng, X. Chem. Commun. 2012, 48, 8117-8119.

(46) Yu, F.; Li, P.; Song, P.; Wang, B.; Zhao, J.; Han, K. Chem. Commun. 2012, 48, 2852-2854.

(47) Ueno, T.; Nagano, T. Nat. Methods 2011, 8, 642.

(48) Yu, F.; Gao, M.; Li, M.; Chen, L. Biomaterials 2015, 63, 93101.

(49) Lebel, C. P.; Ischiropoulos, H.; Bondy, S. C. Chem. Res. Toxicol. 1992, 5, 227-231.

(50) Buxser, S. E.; Sawada, G.; Raub, T. J. Methods Enzymol. 1999, 300, 256-275.

(51) Khan, M. A. K.; Wang, F. Environ. Toxicol. Chem. 2009, 28, $1567-1577$.

(52) Han, X.; Song, X.; Yu, F.; Chen, L. Adv. Funct. Mater. 2017, 27, 1700769.

(53) Hankare, P. P.; Bhuse, V. M.; Garadkar, K. M.; Delekar, S. D.; Mulla, I. S. Semicond. Sci. Technol. 2004, 19, 70.

(54) Kim, H. N.; Ren, W. X.; Kim, J. S.; Yoon, J. Chem. Soc. Rev. 2012, 41, 3210-3244.

(55) Shi, W.; Sun, S.; Li, X.; Ma, H. Inorg. Chem. 2010, 49, 12061210.

(56) Tang, B.; Ding, B.; Xu, K.; Tong, L. Chem. - Eur. J. 2009, 15, 3147-3151.

(57) Samb, I.; Bell, J.; Toullec, P. Y.; Michelet, V.; Leray, I. Org. Lett. 2011, 13, 1182-1185.

(58) Kumar, A.; Singh, J. D. Inorg. Chem. 2012, 51, 772.

(59) Li, Y.; He, S.; Lu, Y.; Zeng, X. Org. Biomol. Chem. 2011, 9, 2606-2609.

(60) Zhang, Q.; Zhu, Z.; Zheng, Y.; Cheng, J.; Zhang, N.; Long, Y. T.; Zheng, J.; Qian, X.; Yang, Y. J. Am. Chem. Soc. 2012, 134, 1847918482.

(61) Lee, M. H.; Kim, J. S.; Sessler, J. L. Chem. Soc. Rev. 2015, 44, $4185-4191$.

(62) Kolanowski, J. L.; Liu, F.; New, E. J. Chem. Soc. Rev. 2018, 47, 195-208.

(63) Pelletier, E. Mar. Environ. Res. 1986, 18, 111-132.

(64) Kalluri, R.; Weinberg, R. A. J. J. Clin. Invest. 2009, 119, 14201428.

(65) Goering, P. L.; Fisher, B. R.; Noren, B. T.; Papaconstantinou, A.; Rojko, J. L.; Marler, R. J. Toxicol. Sci. 2000, 53, 447-457. 